\title{
Sexual Revictimization: Reflections from Contemporary Feminism
}

\author{
Leyla Torres-Bravo \\ Instituto de Estudios Humanísticos, Universidad de Talca (Chile). Email: Itorres@utalca.cl
}

\begin{abstract}
This article reviews the concept of revictimization taking into consideration several interdisciplinary perspectives. Based on this premise, we analyze how contemporary feminism expands on violence against women. After the said analysis, we explore recent studies on sexual revictimization to study how feminism has reflected and intervened in society and academia to provide greater visibility to the multiple phenomena involved in revictimization.
\end{abstract}

Keywords: revictimization, sexual revictimization, violence, contemporary feminism, survivors.

\section{Introduction}

Currently, the presence of an evident discerning background in feminism that calls to an end of inequalities, exclusions, and violence that jeopardize women's life opportunities is undeniable. Thus, a clarifying view emerges to understand the historical-cultural composition of women's reality. At this point, it will become critical to grasp the meanings of violence against women, an issue that requires the unveiling of its manifestations along with the concealment and normalization of discourses still present in daily gender relationships. Due to this simple but no less important reason, the feminist theory as such will escalate its discussion on violence and will question both its historical genesis and re-signified discourses about survivors.

Likewise, this discerning framework of feminism will focus on both the individual expression and collective consciousness from which the status quo can be changed. This discerning base will have to materialize as a space for joint learning and tailored to the task of providing a solution to their plight. Thus, to install this dynamic within a real and shared scenario among women advancing cultural products that collect the experience of their historical memories will be required. Through their broad cultural production, feminists will intensify their exposure and their communiqués, manifestos, conferences, petitions, conference papers, or articles, among many others (Espigado Tocino, 2020), and will be subject to public scrutiny.

In this sense, it should be noted that it becomes relevant to perform a deeper analysis of the links that have led to a new way of studying violence, increasingly willing to incorporate views from other academic disciplines. Under this perspective, the critical task and its impact on the intervention's ability to protect human life are installed with greater emphasis. The feminist

This Open Access article is published under a Creative Commons Attribution Non-Commercial 4.0 International License (http://creativecommons.org/licenses/by-nc/4.0/), which permits non-commercial re-use, distribution, and reproduction in any medium, provided the original work is properly cited. For citation use the DOI. For commercial re-use, please contact editor@rupkatha.com. 
conviction installed through its active and discerning commitment against violence, as we will see below, will have a positive impact on the social view and treatment of survivors.

Based on the aforementioned, this article intends to analyze some of the main ideas regarding violence against women, with a special emphasis on sexual violence, supported by feminism. First, the concept of revictimization is circumscribed and, from there, its socio-cultural scope is briefly analyzed. Secondly, its status is analyzed through contemporary feminism. Lastly, it analyzes the addressed theoretical question through a new language and survivor treatment setting.

\section{The issue of revictimization: an outlook on its dynamics and theoretical views in recent studies}

The presence of multiple forms and channels through which revictimization becomes evident is undeniable; thus, a marked decrease in the subjective well-being of many people around the world takes place. Our starting point is the certainty that revictimization is far from being fortuitous. On the contrary, approaches to the said notion, from a psychology standpoint, reveal that it is a common phenomenon that carries several effects on mental health. Its occurrence is associated with single or multiple traumatic incidents. This reveals the potential presence of repeated aggressions in two or more life stages (Davis, Combs-Lane, \& Jackson, 2002). Hence, in our opinion the several manifestations of contemporary violence perceived as recurrent in society allow us to appreciate how the normalization of violence in survivors and its meaning transpired.

From a criminological standpoint, revictimization or repetitive victimization highlights the fact that it is a phenomenon that encompasses a substantial portion of all victimization cases. Perhaps the most significant portion in this area is the search for an exhaustive knowledge of the patterns involved in revictimization because, through them, it would be possible to provide the means associated with more effective prevention of domestic violence as well as theft and other criminal activities (Farrell, 1995). In this sense, it must be made clear that revictimization poses a huge problem for criminal justice (DePrince, Chu, Labus, Shirk, \& Potter, 2015). But it is also essential to envision strategies that explain and prevent revictimization. One of them is directly associated with the implementation of intervention programs with an emphasis on the prevention or mitigation of revictimization. For this reason, and by way of illustration, it is worth mentioning that new psychological intervention spaces are being created for its mitigation, especially for battered women (Nichols, 2013).

In more specialized revictimization analysis there seems to be a consensus that many survivors may be at an increased risk of revictimization in the near or distant future. According to Messman-Moore and Long (2003), there is sufficient evidence to support the link between childhood sexual abuse and an elevated risk of revictimization during adulthood. Nearly half of the survivors of this type of violence report having suffered new sexual victimization later in life. As it can be seen, this prevalence is remarkably high, estimated to be as high as fifty percent. This also exposes the fact that women are more likely to experience sexual revictimization in adulthood. Thus, it is evident that women who have been sexually abused as children exhibit a three to five times greater risk of revictimization than those who have been sexually assaulted 
only as adults (Castro et al., 2019). However, there is still little or limited evidence to examine more rigorously certain factors that also contribute to the emergence of sexual and non-sexual dynamics linked to revictimization (Papalia, Mann, \& Ogloff, 2021).

As stated previously, interpersonal violence has become a global issue of concern because it threatens the quality of the survivors' lives. Within this context, Bultler, Quigg, \& Bellis (2020) state that interpersonal violence is one of the leading causes of death and functional diversity in the world today. Hence, it is a type of violence that must be prevented, especially in childhood since interpersonal violence highlights the association between childhood sexual abuse and the increased risk of future physical aggression, intimate partner violence, or sexual revictimization during adulthood. Among the theoretical works that address sexual abuse, the phenomenon of sexual victimization and revictimization experiences in men is of special relevance. Such relevance is due, on the one hand, to the fact that it is still scarcely studied. And, on the other hand, it is appropriate to take into consideration that both phenomena are underlying experiences during childhood and adulthood (Charak, Eshelman, \& Messman-Moore, 2019).

As we have seen, revictimization explains the serious issues of high interpersonal violence to which survivors are overexposed in the near or distant future. Victimization leads to a significant decline in self-esteem and subjective well-being. On the other hand, trauma and detachment emerge as relevant consequences of sexual abuse in childhood. In this regard, a positive correlation between a higher rate of childhood trauma and a lower level of self-esteem and subjective well-being experienced during their lives has been found. Therefore, it is desirable to expand our knowledge on these issues, in addition to their value for adequate management of their treatment in the medical field. In this sense, core answers could be provided to favor intervention and repurposing the abandonment of victims or professional ignorance on collaborating with survivors (Barnum \& Perrone-McGovern, 2017). Revictimization stresses that shielding in the face of violence is something to which we must be alert. It offers a point of view that makes much sense about preventive work on violence as well as about the social inclusion of survivors.

All of the above is also related to recent cognitive studies that attempt to verify whether, by accurately detecting transgressions in social contracts, people could avoid interpersonal relationships that harm their physical and mental integrity. However, while such studies aim to improve prevention in survivors, they also rely on an approach that, on the one hand, connects revictimization with erroneous performance during deductive reasoning exercises, and, on the other hand, seeks to validate the existence of specific mechanisms that supposedly operate in the human mind linked to social caution. Following this same line of research, such studies have gone on to link the theory of betrayal trauma with the detection of transgressions through social contracts considering the experiences between the victim and the perpetrator as a caregiver. This is observed when the victim has a close bond of dependency with the abuser. Moreover, there is also no doubt that it is more difficult for the victim to notice the abuse. Thus, the victim will continue to maintain his/her bond of dependency with the person who acts as the aggressor (DePrince, 2005). Regarding such studies, it must be said that, in their view, the risk of revictimization is due to the poor cognitive performance of the survivors. This is a central issue, as they have been previously exposed to violence that entails interpersonal trauma, which evolves to associating the trauma theory with betrayal (Gagnon, Lee, \& DePrince, 2017). However, for López 
(2012), such studies should be closely reviewed. Mainly, because we must avoid falling into positions that take for granted rejected or questioned rewards versus the operation of control mechanisms of social exchanges and risk circumstances in the human mind.

Consequently, it is hard to ignore or omit that there is an urgent need to continue exploring the cognitive, emotional, and sociocultural dynamics that are widely linked to sexual or domestic violence. What is interesting is that the said dynamics can be read at various times and in different contexts following both the survivors' individual experience and family environment. However, sexual aggression as a phenomenon of high interpersonal violence must focus its impact on this, thus, making room for more specific and interdisciplinary studies.

It should be noted that it is essential to continue studying current precedents dealing with revictimization since it is geared towards a disciplinary understanding of the issue. In recent years, new forms of analysis trying to standardize more adequate psychological therapies or that are linked to subjective well-being and quality of life have become evident.

Lastly, another perspective on revictimization links with the social representations constructed by several mass media, whether emerging or traditional. This point of view also allows us to ulteriorly explain how the media discourse and social networks negatively expose the victims.

At any rate, there is also the use of the revictimization concept associated with another analysis perspective. Under the said perspective, it is defined as an issue that brings with it the survivors' psychological deterioration. This also confirms the elevated level of distrust associated with the achievement of justice (Hernández López, 2019), which is also reflected in police investigations and health care. Added to all this, there is a direct impact on the survivors that underlines the bitter memory of the violent experience. Hence, revictimization is conceived as the result of inadequate care procedures conducted by institutions and individuals that are detrimental to survivors (Dupret \& Unda, 2013). In this sense, Bjørnholt (2019) states that revictimization is contingent on social and institutional contexts. It is therefore essential to improve institutional and individual responses to disrupt revictimization. These changes need to incorporate aspects that align with beliefs about inequalities, as well as non-biased attention to specific groups or individuals.

\section{Feminist reflections on violence against women: sexual victimization and revictimization}

A framework of analysis that, in our opinion, confirms the relationship between contemporary violence and feminism has to do with the victimization and revictimization of survivors. In this sense, it should be noted that the feminist theory will study the impact of patriarchy as an oppressive ideology whose roots will give way to a notion of superiority, in so far as it is linked to the public or private staging of violence. This outlook will undoubtedly expand to other spheres of oppression such as current neoliberalism. And, likewise, it will be found linked to other past oppression but with socio-cultural and political impacts still in force, such as post-colonial oppression. Admittedly, most of its historical-cultural meanings consecrate the value of structural genealogies of violence due to its association with diverse oppressive systems whose imperative consists in the subjugation of the otherness. The point is that its legacy has transmuted into new forms of violence that are increasingly subtle, both in representation and action. But, in turn, such 
5 | Sexual Revictimization: Reflections from Contemporary Feminism

a vision will expand to ecological citizenship, social equality, and multicultural coexistence. In other words, it will provide a clarifying answer to the global and structural violence that emerges from broad capitalist rhetoric.

Hence, many concepts will begin to be the parts of our daily language, providing a special place for both individual accountability and self-care. Its support base will be individualism. In this sense, this is confirmed by biopsychosocial well-being. It is there where the current self-care health discourses at work and at home as well as in any aspect of our daily lives are housed. This will make way for a strategy aimed at covering up the last two centuries' social injustices. The issue will be linked to violence, poverty, health, and subjective well-being since they hide or reveal the dehumanization and exclusion of the otherness. Within this context, the governmental and social emphasis on self-care, we believe, is based on the premise that through self-care it is possible to avoid or stun domestic or sexual aggressions. This is how this critical issue is somewhat minimized and confined to the merely individual. Hence, the self-care approach entails the idea that putting an end to aggressions only concerns the assaulted, leaving other relevant actors and the oppressive system that encompasses society without accountability (Vance 1989 cited in Penchansky 2020). On the contrary, for the ethics of nonviolence, the other and his or her vulnerability are connected with our own vulnerability. Therefore, solidarity is one of the aspects that openly oppose contemporary violence, providing spatial room to the other (Butler, 2004).

Hence, visualizing the heavy contribution to the subject that emerged from feminism is possible. It is no coincidence, then, that its focus of interest is to trace the cultural meaning assigned, on the one hand, to citizen participation and, on the other hand, to the historical practices that support contemporary violence. It should also be noted that such a position will be enhanced as a result of its insertion into the public debate. Thus, from the first decades of the $20^{\text {th }}$ century, resistance against male domination has been based on refuting the supposed distinction between men and women in terms of abilities, social roles, and citizenship. Examining this issue in greater depth and as Espigado Tocino (2015) asserts, the collective image of women was built based on their self-affirmation and recognition, along with their antagonist interpellation regarding men. In this sense, during their first speeches and public interventions feminists had to show their adversaries' negative and stigmatized reverse side. Hence and likewise, their affirmation as such will lead them to use a language that opposes social injustice and the entrenchment of aristocratic privileges over merit. Again, it is asserted that by tracing social imaginaries it was possible to verify one of the main significant points assigned to men: their equivalence with evil and tyranny. Thus, feminism emphasized the value investment of the stronger sex, specifically the one underlying any manifestation of male power. This is shown in the origin of certain negative attributes of the father and husband figures. The author concludes that feminism will establish private life as the place of origin of male domination. Therefore, this objective assigns to gender relations a high relevance in her analysis of the radicalization of men's absolute power over women and the family group. All these mechanisms of action will open the way to the general feminist view always constructed in principle and the function of male oppression.

As it can be seen, the way to understand their deconstructive position will be driven by their vast rejection of the socio-cultural consolidation of gender roles and stereotypes. It is obvious that their transgression of the status quo will quickly become a public issue of great 
general interest especially because its role will be to remodel those socio-cultural and everyday gender dynamics on which patriarchy has been based for centuries. According to this imperative, the feminist theory was not only able to incorporate gender in its analysis of the feminine reality but also propitiated its change. Consequently, the theory will always be at the forefront of the feminist claim because it tries to put an end to the historical inequalities associated with gender binarism.

Regarding contemporary violence, the feminist proposal outlines a reflexive potential whose essence is found in the cultural meanings that regulate the repression of subjects in not only traditional societies but also current ones. From there, the way is opened to the notion of the historical-cultural genealogy of violence against women. Here, the feminist theory will have available the binarism of opposites that is configured as a reflexive field from which the multiple oppressions that overwhelm the subjective and diverse realities of women around the world are studied. In this regard, Karen Offen argues that "the male/female relationship is the object and subject of the historical feminist project and in it lie almost all the debates of the past and present" (2012: 82). Therefore, its appropriateness is beyond doubt. Consequently, the acceptance and public legitimization of male power will be ratified, according to feminism, in the traditional and current socio-cultural dynamics related to gender relations. It is clear, then, that the use of gender in the struggle against the undermining of women was what allowed the feminist theory to show the need to address the change of meanings and daily realities of women. However, this point has been somewhat questioned in the debates that have developed in feminist historiography focusing on both gender binarism and woman status. This, resulting from the lack of current recognition of this invariability along with postcolonial criticisms, reflects all its Eurocentrism and its hegemonic character in western history (Blasco Herranz, 2020). Going back to the historical view regarding feminism, Mary Nash's point of view highlights the fact that "feminism is and has been a field of open debate and disagreement" (2014: 28). And presently, this point hints at the difficulty involved in the organization and redefinition of their collective actions. It also confirms the criticisms of global feminism formulated by peripheral feminists. In this sense, it is a matter of emphasizing the growing need to review the feminine actions originating from the complex relation of ethnic subordination with colonial roots. In short, the gender binarism exposed in its relationship with patriarchy constitutes one of the central frameworks of analysis of the feminine subordination condition and the violence exercised against them.

A vastly different view from the previous is the one proposed by postmodernism. In principle, it is appropriate to say that the postmodern approach was erected as an obstacle for feminism. In their opinion, the applicability of a specific discourse, linked to patriarchal oppression and the feminist identity of political order, is beyond doubt basically because such a postmodern assertion questioned their classic premises. For the same reason, it was difficult for traditional feminism to adapt to the subordination and intersections deriving from categories such as social class, culture, or ethnicity. Faced with this, it could also be seen that they were forced to delay the achievement of a general theory. Hence, through their rebellious tone and attitude, their yearnings for social transformation and female emancipation against male hegemony were also disrupted (Cobo Bedia, 2000). 


\section{Sexual violence and view emerging from contemporary feminism}

To talk about sexual violence, we must consider the extent of feminist views, which necessarily implies its historical-cultural context with the task of researching the reasons for its emergence. Regarding the binarism connected to sexual aggression, two options are considered: one is that it argues a matter of power, and the other that it is connected to sex. For Ericksson Baaz and Stern (2018), such a perspective has restricted and nuanced feminist thinking, thus, hindering their task of understanding how social and individual interactions operate in daily life. Deepening into this matter, we can, likewise, consider what Palmer (1988) says when he states that the most common explanation about sexual violence is directly related to the exercise of power or domination, rather than sex. The author stresses that such a view is based on very specific arguments. Therefore, he considers his definitions to be inaccurate or unverifiable in what pertains to the actions conducted by sexual assault perpetrators. Returning to the background of the origin of sexual aggressions, Primorac (1999) warns that there are points of agreement and disagreement when the subject is debated. However, what is important is that this fact by itself brought novel approaches for the treatment of survivors. But it also implied the task of trying to especially understand other issues such as prostitution, abortion, and marriage.

Over time, second-wave feminism includes the issue of sexual violence in the United States. It should be kept in mind that it has been established that the milestone for the beginning of this second-wave feminism will be the publication, in 1963, of Betty Friedan's work: The Feminine Mystique. Equality will be its key concept of vindication as a response to the new interests that affect, above all, women with their entry into the workforce (Abdul Karim \& Azlan, 2019).

Thus, second-wave feminism, as Rodriguez Martinez (2011) states, will take on the task of explaining what drives violence against women. The reason will be assigned to a patriarchal system- a perspective reinforced by the biological difference between men and women. In other words, there is an argument that shifts between the sexual and social control of men that will give ample space to forms of violence against women. All of which will ultimately be reflected in the way gender relations are understood, sensed, and practiced in the different patriarchal societies.

A more specific approach to this debate appears in McPhail (2016) that traces and outlines how radical and liberal feminism explains sexual violence. A radical feminist response to sexual violence against women involves and brings into play multiple dynamics that converge in patriarchy. Additionally, it is clear in its view that both sexual violence and sexual desire in men are founded and regulated by the supposed availability of women (Cobo Bedia, 2015).

From the previous analysis, it can be seen that the feminist interpretation of sexual violence will broaden its perspective and thus contribute to assigning to it a gradual place in the public sphere. It becomes relevant to review this issue since it is the one that mobilizes and questions discursive violence which is still rooted in social relations. The feminist denunciation and claim act as a reinforcement of the feminine reality since it tries to transgress socio-cultural realities embedded in western civilization.

A key aspect is precisely how the media and the socio-cultural discourse have positioned themselves concerning those who have been undermined by this type of violence. It is not by chance, for example, that the discourse on sexual abuse is depicted based on the event's 
exceptionality. And, at the same time, it is assisted by a vast public repercussion. Under this framework, the copious aggressions conducted in homes and during childhood will be covered up. It would be, then, structural violence materialized through a patriarchal narrative. This would end up being the basis used to blame the survivor and exonerate the aggressor (Brandariz Portela, 2021).

In this regard, it is important to note that the second-wave feminist approach by activists and academics in the United States resulted in the advancement of legal reforms and support services for sexual victimization survivors. Indeed, early psychological studies of rape from a gender perspective highlighted how common sexual violence against women has been. In the case of sexual assault, academics concluded that it was much less likely to be perpetrated by a stranger than by a person close to the victim such as a spouse, close family member, or acquaintance (McPhail, 2016).

Beyond this vision of radical feminism, as stated by Lonsway and Archambault (2012), a substantial theoretical change can be seen today regarding the general vision that is formulated about male power and sexual aggression. It was precisely this theoretical position of radical feminism that made it possible to shift the blame away from the victims of sexual aggression. Thus, evident socio-cultural aspects such as physical attraction or the survivors' love and sexual history were subtly distanced from social criticism above all by placing them as less relevant aspects to understand how sexual violence takes place. The interesting thing is that, according to the authors, it is also possible to visualize significant changes in the use of terms more directly associated with aggression, which, by the way, contribute to a more sensible view of sexual aggression and its implications for survivors within the criminal justice system. However, it has certainly not been eradicated.

It should also be noted that feminist efforts regarding contemporary violence have been disseminated through their increasing insertion in the legal framework. For instance, thanks to said efforts penalties for perpetrators increased, in addition to the judicial protection for survivors of sexual and domestic violence episodes (Powell, Henry, Flynn, \& Henderson, 2013). Although, as we have seen, these options have not been entirely successful in curbing violence against women.

In the same vein, Gilson (2016) argues that the central challenge of current feminism is to achieve the banishment of the simplistic interpretation of victims and victimization. A key concept, in this sense, is that of vulnerability because it is heavily charged with negativity which is directly associated with victims. Hence, the author also says that it is an ambivalent term for them considering, on one hand, their reaffirmation as such, or on the contrary, their invisibility. At any rate, the treatment of survivors is a primordial issue, however insistent it may seem. It becomes necessary to show this reality to denounce and change the reinforcement of a new physical, psychological, and social revictimization.

\section{Conclusions}

The concept of revictimization allows us to see the relevance given by the feminist perspective to sexual violence. In this sense, both its reflection and the expansion of knowledge about this 
phenomenon in the $20^{\text {th }}$ century are circumscribed to contemporary violence, from whose historical roots, according to the feminist perspective, are situated the patriarchal aggression against women. We have tried to show some basic perspectives of its proposals. Beyond this, its academic and activist interventions, especially from the seventies onward, allowed us to know more about the social dynamics linked to sexual aggression. From this specific perspective that feminism makes around victimization, the premise that it is possible to change the forms of oppression and daily treatment of women is consolidated. In other words, feminist statements aimed at eradicating contemporary violence against women in physical and virtual spaces. This also has an impact on detecting how violence permeates the realities of many people. In this sense, it would be necessary to eradicate the notorious ignorance and empathy that, on countless occasions, ends up becoming a second social and institutional victimization or revictimization.

That is why current feminism tries to have an impact on the prevention and overcoming of the violent event itself, adding also the subsequent social abuse. It should be noted that in the studies reviewed above the data referring to sexual revictimization shows that this is an extremely prominent issue as it has a significant impact on the visualization of violence and on the ways to avoid revictimization. There is also a need to expand research to study both social thinking and the improvement of the survivors' subjective well-being, self-esteem, and quality of life. All this, in turn, could become a real contribution for professionals who deal with cases of extreme violence in the health, judicial, or educational fields. A permanent dialogue between the different disciplines of knowledge and different perspectives of analysis could also have an impact on the management of new data and evidence, individual treatments, socio-educational interventions, among others. Another transcendental point is overcoming the approach of dealing with survivors through daily language, social networks, media, governmental, and private institutions. Consequently, it can be noticed that contemporary feminism considers violence as an axis of a patriarchal or colonial and historical past against women, but with a constant reprocessing of its ethical and discursive dynamics in the present. From there, we can observe the revaluation of contemporary feminist reflections on violence and its concealment, media visibility, and current significance.

\section{Acknowledgment}

This paper is a result of the Project I+D: "Espacios de conocimiento, cultura y agencia femeninas en el mundo Moderno y Contemporáneo (siglos XV-XX)", PGC2018-097445-B-C21, subproyecto del Coordinado, "Género, cultura y subjetividad: más allá de las políticas del conocimiento (siglos $\mathrm{XV}-\mathrm{XX})^{\prime \prime}$, Ministerio de Ciencia, Innovación y Universidades, España. I also thank research Directorate of the University of Talca (Chile) and its support through the Fund for Intermediate Level Scientific Equipment, of which I am a Co-investigator. 


\section{References}

Abdul Karim, M. H., \& Azlan, A. A. (2019). Modernism and Postmodernism in Feminism: A Conceptual Study on the Developments of its Definition, Waves, and School of Thought. Malaysian Journal of Social Sciences and Humanities (MJSSH), 4(1), 1-14.

Barnum, E. L. \& Perrone-McGovern, K. M. (2017). Attachment, Self-Esteem and Subjective Well-Being Among Survivors of Childhood Sexual Trauma. Journal of Mental Health Counseling, 39(1), 39-55.

Bjørnholt, M. (2019). The social dynamics of revictimization and intimate partner violence: An embodied, gendered, institutional and life course perspective. Nordic Journal of Criminology,20(1), 90-110.

Blasco Herranz, I. (2020). A vueltas con el género: críticas y debates actuales en la historiografía feminista. Historia Contemporánea, 62, 297-322.

Brandariz Portela, T. (2021). Los mitos de la violación en el caso de 'La Manada'. Una crítica a la división patriarcal público / privado. Investigaciones Feministas, 12(2), 575-585.

Butler, N., Quigg, Z. \& Bellis, M.A. (2020). Cycles of violence in England and Wales: the contribution of childhood abuse to risk of violence revictimization in adulthood. BMC Med18, 325.

Butler, J. (2004). Precarious life. The powers of mourning and violence. New York: Verso.

Castro, Á, Ibáñez, J. Maté, B. Esteban, J. \& Barrada, J. R. (2019). Childhood sexual abuse, sexual behavior, and revictimization in adolescence and youth: A mini review. Frontiers in Psychology, 10.

Charak, R., Eshelman, L., \& Messman-Moore, T. (2019). Latent classes of childhood maltreatment, adult sexual assault, and revictimization in men: differences in masculinity, anger, and substance use. Psychology of Men \& Masculinities, 20(4), 503-514.

Cobo Bedia, R. (2015). El cuerpo de las mujeres y la sobrecarga de sexualidad. Investigaciones Feministas, 6, 7-19.

Cobo Bedia, R. (2000). Género y teoría social. Revista Internacional de Sociología, Tercera Época, 25, 5-20.

Davis, J. L., Combs-Lane, A. M., \& Jackson, T. L. (2002). Risky behaviors associated with interpersonal victimization. Journal of Interpersonal Violence, 17, 611-629.

DePrince, A. P., Chu, A. T., Labus, J., Shirk, S. R., \& Potter, C. (2015). Testing two approaches to revictimization prevention among adolescent girls in the child welfare system. Journal of Adolescent Health, 56, 533-539.

DePrince A.P. (2005). Social cognition and revictimization risk. Journal of Trauma Dissociation, 6 (1), $125-$ 41.

Dupret, M. y Unda, N. (2013). Revictimización de niños y adolescentes tras denuncia de abuso sexual. Universitas, XI (19), 101-128.

Eriksson Baaz, M. \& Stern, M. (2018). Curious erasures: the sexual in wartime sexual violence. International Feminist Journal of Politics, 20(3), 295-314.

Espigado Tocino, G. (2020). De lo individual a lo colectivo: constituir red y sociedad en femenino durante el Sexenio Democrático. Bulletin d'Histoire Contemporaine de l'Espagne [En ligne], 55. Retrieved from http://journals.openedition.org/bhce/1563. doi: https://doi.org/10.4000/bhce.1563.

Espigado Tocino, G. (2015). Preparando el camino de la emancipación: voces críticas y acción colectiva femenina en el XIX. En Yusta, M. y Peiró Martín, I. (Coords.), Heterodoxas, guerrilleras y 
ciudadanas. Resistencias femeninas en la España moderna y contemporánea (pp. 85-113). Zaragoza: Institución Fernando el Católico.

Farrell. G. (1995). Preventing Repeat Victimization. Crime and Justice, 19, 469-534.

Gagnon, K.L., Lee, M.S., \& Deprince, A.P. (2017). Victim-perpetrator dynamics through the lens of betrayal trauma theory. Journal of Trauma \& Dissociation, 18, 373-382.

Gilson, E. C. (2016). Vulnerability and victimization: Rethinking key concepts in feminist discourses on sexual violence. Signs: Journal of Women in Culture Society, 42 (1 Autumn), 71-98.

Hernández López, I. (2019). 'Aesthetic Attention': Exploring the Possibilities of Interaction Design to Reduce Revictimization. Diseña, 15, 140-161.

Lonsway, K. A. \& Archambault, J. (2012). The "Justice Gap" for Sexual Assault Cases: Future Directions for Research and Reform. Violence Against Women, 18 (2), 145-168.

López, M. (2012). Revictimización y procesamiento de la información: problemas en el estudio de las dificultades de razonamiento. Cinta moebio, 44, 153-168.

McPhail, B. A. (2016). Feminist Framework Plus: Knitting Feminist Theories of Rape Etiology into a Comprehensive Model. Trauma, Violence, \& Abuse, 17 (3), 314-329. doi: $10.1177 / 1524838015584367$.

Messman-Moore, T. L. y Long, P. J. (2003). The role of childhood sexual abuse sequelae in the sexual victimization of women. An empirical review and theoretical reformulation. Clinical Psychology Review, 23, 537-571.

Nash, M. (2014). Los feminismos históricos: revisions y debates. En Cenarro, Á. y Illion, R. (Eds.), Feminismos. Contribuciones desde la historia (pp. 27-50). Zaragoza: Prensas de la Universidad de Zaragoza.

Nichols, A. J. (2013). Survivor-Defined Practices to Mitigate Revictimization of Battered Women in the Protective Order Process. Journal of Interpersonal Violence, 28 (7), 1403-1423. doi:10.1177/0886260512468243.

Offen, K. (2012). "Flujos y erupciones": reflexiones sobre la escritura de una historia comparada de los feminismos europeos, 1700-1950. En A. Cova (Ed.), Historia comparada de las mujeres. Nuevos enfoques (pp. 57-83). Trabe: Oviedo.

Palmer, C. (1988). Is rape a cultural universal? A re-examination of the ethnographic data. Ethnology, 28, 1-16.

Papalia N, Mann, E., \& Ogloff, J.R.P. (2021). Child Sexual Abuse and Risk of Revictimization: Impact of Child Demographics, Sexual Abuse Characteristics, and Psychiatric Disorders. Child Maltreatment, 26 (1), 74-86. doi:10.1177/1077559520932665.

Penchansky, M. C. (2020). Entre el placer y la victimización: reflexiones en torno a la sexualidad y los discursos antivíctima bajo la gubernamentalidad neoliberal. Las Torres de Lucca, 9 (17), 167-192.

Primorac, I. (1999). Radical feminism on rape. Društvena istraživanja-Casopis za opća društvena pitanja, 8 (4), 42, 497-511. Retrieved from https://hrcak.srce.hr/20312.

Powell, A., Henry, N., Flynn, A. L. G., \& Henderson, E. (2013). Meaning of 'Sex' and 'Consent': The persistence of rape myths in Victorian rape law. Griffith Law Review, 22 (2), 456-480. Retrieved from https://doi.org/10.1080/10383441.2013.10854783.

Rodríguez Martínez, P. (2011). Feminismos periféricos. Revista Sociedad \& Equidad, 2, 23-45. 